REPORT

\title{
Modal Metaphysics: Issues on the (Im)Possible VII*
}

On May 30-31, 2019 the Institute of Philosophy of the Slovak Academy of Sciences, the Slovak Philosophical Association, the Department of Logic and Methodology of Sciences at Comenius University and metaphysics.sk hosted the seventh Issues on the (Im)Possible Conference. As usual, the conference was hosted by the Slovak Academy of Sciences in Bratislava.

Beside the conference itself, the event accommodated three additional streams: Current Trends in Deontic Logics II, Semantics of Fictional Discourse II and Truth in Time and Open Future Stream II. Given the size as well as the scope of the conference, it was rather unsurprising that the organizers invited more keynote speakers. Namely: Jan Broersen (University of Utrecht, The Netherlands), Gregory Currie (University of York, UK), Peter van Inwagen (University of Notre Dame, USA), Peter Lamarque (University of York, UK) and Scott Shalkowski (University of Leeds, UK).

During two intensive days, the following speakers contributed to the conference: Kirk Lougheed (McMaster University): "Epistemically Possible Worlds and the Counterpossible Objection to the Axiology of Theism" (Commentator: Ethan Brauer); Gonzalo Rodriguez-Pereyra (Oxford University): "Are the Laws of Metaphysics Metaphysically Necessary?"; Yael Loewenstein (University of Houston): "Against the Standard Solution to the Grandfather Paradox (And How Not to Understand Time-Indexed Modals in Contexts with Backwards Causation)" ; Nathan Wildman (Tilburg University / TiLPs): "Necessity by Accident" (Commentator: Felipe Andrés Morales Carbonell); Martin Glazier (University of Hamburg): "What Time is it in Other Possible Worlds?"

*Martin Vacek

Institute of Philosophy, Slovak Academy of Sciences, Klemensova 19, 81109 Bratislava, Slovakia

凶 martinvacekphilosophy@gmail.com

(C) The Author. Journal compilation (c) The Editorial Board, Organon F.

This work is licensed under a Creative Commons "Attribution-NonCommercial 4.0 International" license. 
(Commentator: Yael Loewenstein); Michael De (University of Bern): "Truthmakers or Truthmaking Supervenience?" (Commentator: Nathan Wildman); Benjamin Marschall (University of Cambridge): "Carnap's Internal Platonism" (Commentator: Karol Lenart); Michael Bertrand (Auburn University): "Two Concepts of Metaphysical Grounding" (Commentator: Dirk Franken); Jan Heylen \& Felipe Morales (KU Leuven): "Circularity and Modality" (Commentator: Anthony Fisher); Augusto Trujillo Werner (University of Malaga): "Metaethics: Aquinas, Hume and Moore"; Dan Marshall (Lingnan University): "Against Linguistic Ersatzism" (Commentator: Michael De); Krzysztof Wójtowicz (University of Warsaw): "The Modal Character of Program Explanations" (Commentator: Mike Bertrand); Peter Marton (Bridgewater State University): "Without Conceivability. (A Moderate Anti-Realist Approach to Possibility, Meaning ... and Zombies)" (Commentator: Giacomo Giannini); Karol Lenart (Jagiellonian University): "Actualism and Haecceitism" (Commentator: Zach Thornton); Vladimir Lobovikov (Ural Federal University): "Analytical Metaphysics of Modalities, and a Formal Epistemology Axiomatic System Based on Not-Normal Modal Logic" ; Riccardo Baratella (Universität Salzburg): "No Chance for the Change Argument A Reply to Stouts The Category of Occurrent Continuants" (Commentator: Benjamin Marschall); Rheanna Trevino (University of Texas at San Antonio): "Actualism and Being: Ontological Commitments and Modal Logic" ; Dirk Franken (University of Mainz): "On Confusions of Ground and Existence" (Commentator: Alessandro Torza); Anthony Fisher (University of Manchester): "David Lewis and the Role of Theoretical Virtues in Metaphysics" (Commentator: Nathan Wildman); Giacomo Giannini (Durham University): "A Crowded World. Dispositionalism and Necessitism" (Commentator: Dan Marshall); Alessandro Torza (National Autonomous University of Mexico): "Ground and Modality" (Commentator: Martin Glazier); Ethan Brauer (Ohio State University): "Metaphysical Nihilism and Modal Logic" (Commentator: Krzysztof Wójtowicz); Zach Thornton (University of North Carolina at Chapel Hill): "Distinctness as Possible Difference" (Commentator: Peter Marton); Michael Wallner \& Anand Jayprakash Vaidya (University of Graz \& San Jose State University): "The Structure of Essentialist Explanations of Necessity" (Commentator: Riccardo Baratella).

Streams were represented by the following speakers respectively: Current Trends in Deontic Logics II: Roberto Ciuni (Department FISPPA): "Information based Oughts and their Interaction with Knowledge and Beliefs"; Tereza 
Novotná (Brno University): "Network Analysis in Law"; Meha Mishra (Indian Institute of Technology Kanpur): "Tolerating Inconsistencies: A Study of Logic of Moral Conflicts"; Igor Sedlár (Czech Academy of Sciences): "Hyperintesional Deontic Logic" and Daniela Glavaničová \& Matteo Pascucci (Slovak Academy of Sciences and Comenius University in Bratislava \& Slovak Academy of Sciences and TU Wien): "Defining Responsibility".

Semantics of Fictional Discourse II: Marco Hausmann (Ludwig Maximilians Universität München): "Fictional Realism and Negative Existentials: Why Kripkes Proposal Fails"; Manuel Rebuschi (Université de Lorraine): "IF Modal Logic for Fictions"; Fredrik Stjernberg (Linkoping University): "The No-name Theory of Fictional Names" and Elisa Paganini (Università degli Studi di Milano): "Fictional Knowledge".

Truth in Time and Open Future II: Daniel Steele (University of Dallas): "The Indeterminacies of Future Contingent Propositions"; Vincent Grandjean (University of Neuchatel): "A Model for the Open Future" ; Andrew Cortens (Boise State University): "On the Metaphysical Necessity of the Past"; Elton Marques (University of Rio de Janeiro): "What is Fatalism?"; Jacek Wawer (Jagiellonian University in Krakow): "Ockhamism without Molinism" and Roberto Ciuni \& Carlo Proietti (University of Padua \& University of Amsterdam): "Postsemantics and the Future Contingents Problem".

Of course, unless such a line-up were present, the conference would not be such a success. On behalf of the organizers, I would like to thank again the speakers for extending the bounds of impossibility.

Martin Vacek

Organon F 26 (3) 2019: 537-539 